\title{
Very Low Birth Weight
}

National Cancer Institute

\section{Source}

National Cancer Institute. Very Low Birth Weight. NCI Thesaurus. Code C114935.

Birth weight less than 1500 grams. 